\title{
COMMUNITY PARTICIPATION IN TOURISM MANAGEMENT OF DIPOWINATAN TOURISM VILLAGE IN YOGYAKARTA
}

\author{
Rumsari Hadi Sumarto \\ Fakultas Ilmu Administrasi, Universitas Brawijaya \\ rumsarimpa@gmail.com
}

\begin{abstract}
Along with the culture changing of modern society that positions tourist visits as a necessity, Yogyakarta has become a tourist destination for tourists. However, if it's observed, the existing destinations have not shown significant development. The destinations offered are still old destinations such as Malioboro and surrounding areas which are tourist icons in Yogyakarta. Meanwhile, other districts in Yogyakarta keep on developing tourist destinations in their area. Therefore, Yogyakarta needs to find new breakthroughs to keep attracting tourists. Tourism village development needs to be intensified so that it can become a cultural tourism destination. However, the tourism village has not been widely known by the public. In the implementation of policies in the tourism field, community participation in tourism villages has not been managed intensively. Based on the background, this study aims to describe and analyze community participation in tourism management, especially Dipowinatan Tourism Village in Yogyakarta. This research uses qualitative research. Through the Community Based Tourism (CBT) approach, residents feel that they have a cultural tourism destination in their area and participate in developing these destinations and can increase the economic income of the residents. Thus, to realize sustainable tourism, there is a need for participation from the community where the community is involved in the implementation of tourism policies through the management of tourism villages.
\end{abstract}

Keywords: Tourist destination, Participation, Policy Implementation

\section{Introduction}

\subsection{Background}

Tourism in the current era is of concern to every country and every region, considering that tourists visit to tourist destinations are increasing. Thus, every country and every region are currently focusing on the development and development of tourism in the region so that tourism in the area becomes more widely known to the public. The study of tourism development and construction has been widely reviewed by Pitana and I Ketut Surya Diarta (2009), Sunaryo (2013), Damanik (2013), and Sedarmayanti (2014). Specifically, tourism development policies were reviewed by Sunaryo (2013). Tourism development policy by Sunaryo (2013) is more focused on Community Based Tourism (CBT). In CBT, community participation is needed for the development of tourist destinations in the area. Community participation was also reviewed in public policy studies among others proposed by Brinkerhoff and Benjamin L. Crosby (2002), Winarno (2008), Tahir (2015), Abidin (2016), Public participation in the context of governance is a vital role besides other actors such as government and the private sector ( Sjamsuddin (2005), Sumarto (2009), Bevir (2011), Kartika et al. (2012), Sedarmayanti (2012), Hakim (2013). Thus, community participation, especially in tourist areas is very important because community is a vital actor for developing 
tourist destinations where the community is close to or within the tourist destination environment.

Yogyakarta is also one of the tourist destinations where tourists are currently visiting tourist attractions in Yogyakarta. But if observed from the attractions offered, the development of tourism objects in Yogyakarta has not shown significant development. Physical changes to be more attractive to tourists are seen in the area around Malioboro. But the significant impact after Yogyakarta is known as a city of tourism is more likely to be the rise of hotel development. The Governor of DIY responded to the development of the hotel by saying that:

There are many hotels in the middle of the district and city due to Regional Regulations (Perda) of Regional Spatial Planning in each region does not regulate in detail. The Regional Regulations of Regional Spatial Planning should regulate the details so that development can be controlled. http:/ /jogja.tribunnews.com/2015/04/01/sri-sultan-gerah-lihat-hotel-diyogya-menjamur (accessed on 2 September 2017)

The rise of hotel construction has actually been anticipated by Yogyakarta Mayor Regulation Number 55 of 2016 concerning Hotel Development Control. However, many licensing applications have entered Yogyakarta City Licensing Service.

By seeing the rampant construction of the hotels in Yogyakarta, as if the development of a tourist destination itself was sunk in the presence of hotels in every corner of Yogyakarta. The destinations offered are still an old destination which in turn has an impact on decreasing the number of tourists because tourists are always shown on old tourist destinations. According to the data from Yogyakarta Special Tourism Statistics Book of 2017, the number of tourist visitors to several tourist destinations in Yogyakarta has decreased, including Kraton, which has decreased from 601,593 in 2015 to 2017 , down to 587,041 and in 2017 to 546,490. Gembira Loka also decreased from $1,824,810$, down to $1,657,431$ and in 2017 to $1,509,358$. If this phenomenon is not immediately anticipated, then tourists can divert their tourism destinations to new destinations that are thriving in four districts in the Special Province of Yogyakarta, namely Sleman, Bantul, Kulon Progo and Gunung Kidul.

Thus, this needs to be a concern of Yogyakarta tourism activists so that Yogyakarta is able to present attractive destinations for tourists. Therefore, it is appropriate for Yogyakarta to seek a new breakthrough so that it can attract more tourists to visit Yogyakarta. One of the tourist destinations in Yogyakarta is a tourism village. Tourism villages in Yogyakarta need to be developed so that they can become attractive cultural tourism destinations for tourists.

The development of tourism villages in Yogyakarta is actually a concern of Yogyakarta City Government, namely the presence of Yogyakarta Mayor Regulation No. 115 of 2016 concerning the Implementation of Tourism Villages. However, in reality the development of tourism villages has not been managed intensively so that it is not yet widely known to the public. 
Seeing these problems, it can be said that Yogyakarta City Government has not totally developed tourist destinations especially in the implementation of tourism villages. In the implementation of policies in the tourism sector at least it can be said that Yogyakarta City Government has not fully intensified community participation in the process of implementing policies in tourism.

Research on public participation in tourism areas has been widely published, among others by Krutwaysho \& Bill Bramwell S. (2010), Butler (2016), Suntikul et al. (2016), Harto (2017), Pradono et al. (2017). However, research reviewing community participation in tourism villages that carry more cultural themes has not been widely discussed.

Research on tourism problems in Yogyakarta must be more focused on how people can participate in the implementation of the tourism village, considering the tourism village is not widely known by the community. People in Yogyakarta Tourism Village need to be supported at least to participate in tourism management in Yogyakarta. One of the tourism villages in Yogyakarta is Dipowinatan tourism village. Dipowinatan tourism village at a glance has not been known well by tourists.

Thus, in order to realize sustainable tourism and support Yogyakarta as a city of tourism, there is a need for community participation that needs to be involved in the implementation of policies in the field of tourism through the management of tourism villages, especially in Dipowinatan Tourism Village in Yogyakarta.

Based on the background of the problems that have been described, the formulation of the problem in this study is how the community's participation in the management of tourism in Yogyakarta Tourism Village is?

The research objective of Community Participation in Regional Tourism Management, A Study of Community Participation in the Management of Regional Tourism in the Dipowinatan Tourism Village in Yogyakarta is to describe and analyze matters relating to community participation in tourism management in Dipowinatan Tourism Village in Yogyakarta.

\subsection{Conceptual Framework}

\subsubsection{Good Governance in Bureaucratic Reform}

The bureaucracy that was built in the beginning was to create regularity in the governance process. The existence of a clear division of tasks and a hierarchical structure is carried out so that the administration of the government can run smoothly and regularly including services to the public. However, the realization of the bureaucracy is perceived negatively by the community and becomes a bad record for the community that intersects with the bureaucracy. According to Ramlan Surbakti, the bureaucratic phenomenon in Indonesia, the great authority possessed by bureaucrats so that almost all aspects of people's lives are handled by the bureaucracy. Finally, it is natural if bureaucracy is then considered as a source of problems or burdens of community rather than a source of solutions to problems faced by community (Santosa 2008: 115). Bureaucracy should be the foundation of the community to solve the problem. However, the bureaucracy on the contrary becomes a burden for community 
because it is slow in solving problems in society. Thus, it needs an action to overcome the gap between community expectations and the behavior of bureaucrats who are less responsive to public expectations. Bureaucratic reform is at least able to answer the weaknesses in the bureaucratic system. One answer that is in line with bureaucratic reform is good governance. According to Santosa, governance is a new paradigm in the order of governance. There are three pillars of governance, namely the government, private sector and society (2008: 130$)$.

The role of the government in good governance is no longer a central role, but the administration of government including the implementation of public services is collaboration with the public and the private sector. According to Santosa, good governance is often interpreted as an indicator of the realization of bureaucratic reform with the fulfillment of principles such as community participation, upholding the rule of law, transparency, concern for stakeholders, oriented to consensus, equality, effectiveness and efficiency, accountability and strategic vision (2008: 122). Sedarmayanti added that the basic principle underlying the difference between governance conceptions and traditional patterns of governance lies in the existence of such strong demands that the role of government be reduced and the role of the community, including the business world and non-government organizations / nongovernmental organizations, is increasingly enhanced and open access (2009: 295).

In good governance, increased community participation is included in public policy making. The impact of community participation in the administration of government will have a real impact and can be truly felt by the community because basically people are more aware of the situation and condition of the region.

\subsubsection{Public Policy Implementation}

Understanding public policy is basically the direction of action taken by the government, the study area includes all actions taken by the government and has an influence on widely society interests (Winarno 2008: 30). Harold Laswell and Abraham Kaplan added that public policy should contain the objectives, values, and social practices that exist in society (Subarsono 2009: 3).

Hence, formulated public policies at least take notice of the ethical values that exist in community, in the sense that the policies implemented do not harm the people affected by the policy. Even the policies implemented at least have a positive influence on widely community interests.

Subarsono said that when policies contain values that are contrary to the values of life in community, then the policy will get resistance when implemented. Conversely a public policy must be able to accommodate the values and practices that live and develop in community (2009: 3). Hence, the formulation of policies must still pay attention to values, norms, pay attention to the public interest and the life of the community so that the implementation does not cause conflict in community. In reality the values and norms are not always presented in the formulation of public policies so that when policies are implemented there arises opposition from the community. 
Lele said that public policy is often one of the basic causes of the conflict in the conflict room (2016: 1). According to Deborah Stone, each agenda always has inclusion and exclusion implications. This means that there is always a group of people who receive the benefits of a policy and another group who do not enjoy anything, even have to bear the risk or loss (Lele 2016: 11). The case that occurred in Yogyakarta about the rampant construction of the hotels in fact actually led to conflict with communities affected by negative impacts such as the clean water crisis.

Therefore, in the implementation of a policy must pay attention to anyone who is affected by the policy in order to minimize conflict from those who feel aggrieved with the implementation of the policy that was rolled out. In some cases the community is often affected by the implemented policies. Although the community is also involved in the formulation of policies but at the time of implementation the community often becomes the audience of the implementation of a policy. The community should be given space to participate in policy implementation.

\subsubsection{Implementation of Public Policy in Tourism Management through Community} Participation

Tourism has become an integral part of the development of a country. Even a country has become better known by public in other countries because of the tourist attraction of tourist destinations in the country. Even with the increase in tourism activities in an area, the economic stretching is also present at the place.

Sunaryo said that in the history of development in many countries, the tourism sector has proven to play an important role in contributing to its economic development, especially in the last two decades, which is shown by the increasing level of economic prosperity of nations that make tourism as its downstream industry to leverage the growth of activities effort and employment of business sectors that are in front of and behind it (2013: 33).

Thus, it is not surprising that every country and even every region are competing to provide attractive tourist destinations so that the country or region can increase the number of tourists. By increasing tourism activities in a country or region, it will have a direct impact in improving the economy in a particular country or region.

Therefore, tourism policy in an area needs to be the focus of attention so that it needs to be designed properly and ethically so that its implementation does not experience problems due to conflicts of interest in regional tourism management.

To minimize conflict, people should be included in the implementation so that community participation can reduce tensions that occur in a policy implementation. According to the World Bank, participation can be defined as a process through which stakeholders influence and share control over development initiatives and decisions and resources which affect them (Brinkerhoff and Benjamin L. Crosby 2002: 53).

As for Brinkerhoff and Benyamin L. Crosby, types of participation can be distinguished, namely information sharing, consultation, collaboration, collaborative decision making, empowerment, for example: community empowerment (2002: 65 $70)$. 
In the perspective of good governance in the field of tourism, the planning concept of community based tourism development needs to be realized. Communitybased tourism development can motivate people to play an active role in tourism activities. Citizen participation in governance is the involvement of residents in making decisions regarding the use of public resources and solving public problems for regional development (Sumarto 2009: 109).

Some definitions of Community Based Tourism Development (CBT) according to Murphy are: (1) the form of tourism governance that provides opportunities for local communities to control and be actively involved in the management and development of existing tourism, (2), the form of tourism management can also be provide opportunities for people who are not directly involved in tourism businesses to get the benefit, (3) Forms of tourism that demand systematic and democratic empowerment and fair distribution of benefits to disadvantaged communities in the destination (Sunaryo 2013: 139).

The tourism development approach through CBT should be applied in the regions so that people feel they have a tourist destination and participate to develop tourist destinations in their area so that they can be better and can increase the economic income of the surrounding communities. The community can be empowered by participating in managing tourism in the area so that the community is able to show their existence in the management of tourism in their area.

According to Draje and Paula, there are several ways or strategies that can be developed in a participatory planning approach or based on Community Based Tourism Development (CBT), namely: (1) Discussing any tourism development project to the community (2) Ensuring that the project objectives can guarantee the benefits achievement and benefits received by local groups / communities, so that they play an active role in supporting the project (3) Always developing capacity building for the relevant community groups so that they understand their role in improving the sustainability of tourism development, (5) Fairer distribution of tourism benefits to local beneficiaries (local beneficiaries) (Sunaryo 2013: 142 - 143). The community is not a passive party in tourism management in the area, but the community plays an active role in tourism development projects. Even the community can support the sustainability of tourism in the area so that tourists can get to know tourist destinations in the tourism area around the community. It must not be ignored that the benefit sharing from tourism development projects in the area can be felt by the community.

Hence, local communities directly involved in the tourism industry can feel the positive impact. The community can feel justice for the acquisition of profits from tourism development in their area. The community is not a marginalized party but is able to contribute positively to develop tourism in the region.

It is appropriate that local community in tourist areas is given space for participation so that they are able to become human resources that can increase the tourism potential in their area. The community at least understands how to develop tourism in their area with a concept that still benefits the surrounding community. 
Thus, profits are not merely enjoyed by the private sector, which in this case has the potential to benefit from the capital invested in tourism areas.

\section{Research Method}

This research uses qualitative research. According to Patilima, qualitative research as a process of inquiry to understand social problems or human problems is based on holistic image creation formed by words, reporting the views of informants in detail and arranged in a scientific setting (2016: 3). Through qualitative research, researchers can find out the messages, responses, responses and perceptions of all parties concerned with community participation in tourism management in Dipowinatan Tourism Village in Yogyakarta.

Based on the problem formulation, the focus of this research is community participation in tourism management in Dipowinatan Tourism Village in Yogyakarta, which consists of: (a) Types of community participation in tourism management in Dipowinatan Tourism Village in Yogyakarta, (b) Process of community participation in tourism management in Dipowinatan Tourism Village in Yogyakarta.

In this study, the main research instrument is the researcher herself. According to Sugiyono, researcher will go into the field both on the grand tour questions, the focused and selection stage, data collection, data analysis and making conclusions (2016: 61). Researcher goes directly to data collection and data analysis techniques. Then the researcher makes conclusions from the results of the study.

Data sources consist of parties who support community participation activities in Dipowinatan Tourism Village in Yogyakarta in the field of tourism. From the data sources, the researchers obtained information about the activities of community participation in the management of tourism in Dipowinatan Tourism Village in Yogyakarta.

The research is located in Dipowinatan Tourism Village in Yogyakarta. The reason for choosing the location of the study is because Dipowinatan Tourism Village in Yogyakarta still holds a strong cultural tradition that can be used as an 'icon' of cultural tourist destinations in Yogyakarta, but the existence of the village has not been widely known by public.

To get the desired and appropriate data in this study, it is necessary to find the right data collection method. Data collection methods used are observation methods, in-depth interviews, and documentation. In observation, researcher is involved with the daily activities of the community who are being observed or used as research data sources (Sugiyono 2016: 64). Observations were made to see the activities of the community participation of Dipowinatan Tourism Village in tourism management directly. In the in-depth interview method, the information extracted is the activity of community participation in tourism management. While the documentation method was obtained through the search for various documents such as regulations, images, records, history and reports. 
For data analysis techniques, Bogdan said that data analysis is the process of systematically searching for and compiling data obtained from interviews, field notes, and other materials, so that they can be easily understood, and findings can be shared with others (Sugiyono 2016: 88). Data analysis is a part of describing what has been successfully understood from the research problem so that it can generate a conclusion. Then the researcher gives recommendations from the research that has been done.

\section{Findings And Argument}

Yogyakarta is one of the areas known by tourists with its trademark as a cultural city. Thus, tourists who come to Yogyakarta will at least perceive that tourist visits will be traversed with performances of cultural attractions and other cultural tourism. However, tourists who visit Yogyakarta in general are more familiar with Malioboro, Kraton, Taman Pintar, silver tours in Kota Gede, Gembira Loka zoo and culinary tours. The rest of the tourists will continue their tour to other regions such as Sleman, Bantul, Kulon Progo and Gunungkidul. Other cultural tourisms have not yet become a tourist agenda for tourists in Yogyakarta.

Actually Yogyakarta has tourism villages that can be visited by tourists. Even the development of tourism villages in Yogyakarta is strengthened by the Mayor Regulation of Yogyakarta Number 115 of 2016 concerning the Implementation of Tourism Villages. However, tourists have not fully known the tourism villages in Yogyakarta.

This problem is in line with what was conveyed by Mr. Sigit, the Administrator Head of Dipowinatan Tourism Village (interview, 22 December 2017):

In general, the tourism villages in Yogyakarta are not widely known by public because they have not been optimized for their management. The institution also has not been professionally organized. Managing HR is also not professional in managing tourism villages.

It can be understood that the tourism village is indeed a village where residents live and its activities are more of a daily activity of residents. To focus on managing the tourism village is not the main goal because people are doing more routine work in their lives.

However, in contrast to other tourism villages, Dipowinatan Tourism Village from the institutional side is actually well organized.

The management of the tourism village has been arranged in Dipowinatan Tourism Village. Each of the management has already knew his duties and responsibilities when this village was visited by tourists. This village also coordinates with other villages for culinary and craft tourism (Interview with Mr. Sigit December 22, 2017)

Therefore, the institutions in Dipowinatan Tourism Village are basically well organized. This is in line with the direction of tourism development policy in 
Yogyakarta, is that Indonesia's tourism development is tourism development originating from the people, by the people and for the people. Based on this concept, the concepts that should be used as the basis are: Community Based Tourism and Sustainable Tourism (DIY Tourism Strategic Plan 2012-2017).

It's also affirmed by Mr. Sigit, the Administrator Head of Dipowinatan Tourism Village:

The development of Dipowinatan Tourism Village is indeed communitybased where the community itself manages cultural tourism such as preparing cultural attractions that will be displayed if there are tourists visiting and other preparations (Interview on December 22, 2017).

Mr. Triawan, one of the residents of Dipowinatan Tourism Village, said that the majority of tourists came from abroad and the largest were from the Czech Republic. For domestic tourists, they haven't visited Dipowinatan Village yet. Then the most visited craft tours include bag making and leather puppet making (Interview 7 December 2017).

The variety of community participation is carried out when holding cultural attractions. The type of participation of the residents of Dipowinatan Tourism Village is to prepare cultural, culinary and craft attractions. People already understand what their duties are when tourists come. For cultural attractions, the community prepares the types of dances that will be displayed, tourist reception ceremonies. For crafts, residents have prepared what kind of craft will be displayed to tourists. Residents are empowered through the appearance of traditional cultural attractions, for example dancers from the residents of the Dipowinatan village, the center of the puppet industry, culinary as well as from local residents (Interview with Mr. Sigit on December 22, 2017)

Involvement of community participation at the time the cultural attraction held was really prepared to attract tourists visiting the Dipowinatan Tourism Village.

For tourists who come we also invite to go to Dipowinatan village to see the lives of the people closely. There are also visiting Java Family activities that we provide to visitors, "Sigit said. This activity was a visit to the house of one of the residents of Dipowinatan village. Tourists can see how the Javanese people welcome guests there, such as serving drinks and food by squatting. In Dipowinatan tourism village there are also a number of traditional arts that tourists can enjoy, ranging from Javanese classical dance, children Jathilan, karawitan, and also bregodo group.http://jogja.tribunnews.com/2016/09/24/berwisata-dan- 
mengenal-tradisi-jawa-di-kampung-dipowinatan-yogyakarta?page=3

(accessed 2 September 2017)

For the attractions shown, the tourists are asked to pay the contributions, i.e.:

Foreign tourist rates range from 15 US dollars to 45 US dollars. While domestic tariffs are Rp 100,000 / person to learn social order (Javanese house, tradition, history of Yogyakarta, how to educate children in Javanese culture) around 3.5 - 5 hours, 150,000 / person for the tradition of anniversary, birthday parties, important moments of tourists, giving souvenirs (Interview with Mr. Sigit December 22, 2017)

The contributions of tourists are then realized for the development of Tourism Villages and the purchase of facilities and tools that can be utilized by the community. This was conveyed by Mr. Sigit:

Tourists' contributions are given back to residents in which one of them is to buy tools such as tables, chairs, sound systems and others that can be used for community needs. (Interview December 22, 2017)

For the participation process, the residents of Dipowinatan Tourism Village carry out the process when the attraction is carried out or when tourists visit and other things related to tourism in the Tourism Village.

According to Mr. Triawan, one of the residents of Dipowinatan Tourism Village, the process of residents' participation was after the residents got information that there would be tourists who would visit, so the residents prepared the art performances that would be displayed. Tourists must provide information in advance so that residents can prepare cultural attractions to be displayed for the tourists (Interview 7 December 2017)

After a schedule has been set, the residents prepare and demonstrate cultural attractions and other preparations related to the tour series.

Not only relying on existing potential, but also being able to attract tourists to come to Dipowinatan, this village tour is packed as attractive as possible. Every tourist who comes will be welcomed by the presence of Bregodo, get a flower bouquet, and welcome drink. For foreign tourists, when traveling around the village they will be accompanied by a guide who masters English and Czech language. Http://jogja.tribunnews.com/2016/09/24/berwisata-dan-mengenaltradisi-jawa-di-kampung-dipowinatan -yogyakarta? page $=3$

The process of preparing cultural attractions in the Dipowinatan Tourism Village is started from the beginning stated by Mr. Tony, one of the residents: 
Tourism Village is managed by the management chaired by Mr. Sigit. Mr. Sigit will inform residents to prepare cultural attractions and other activities. Mr. Sigit also communicated with Yogyakarta Tourism Office in developing Dipowinatan Tourism Village (Interview 8 December 2017)

Therefore, the approach to tourism development through Community Based Tourism (CBT) should be applied so that residents feel they have a tourist destination in their area and participate in developing these destinations and can increase the economic income of the residents. Thus, the residents can get the benefit from tourism development.

Even though the existence of Dipowinatan Tourism Village is not very well known, at least the residents in the Village are serious in managing tours in their area. However, not all residents can participate in managing the tourism village because of their work activities. Yogyakarta Tourism Office needs to motivate residents in the tourism village to jointly promote Dipowinatan tourism village so that there is a synergistic interaction between the residents and Yogyakarta Government in introducing the tourism village.

Thus, it is necessary to collaborate intensively with Yogyakarta Tourism Office and the residents to promote Tourism Villages in Yogyakarta, especially Dipowinatan Tourism Village.

\section{Conclution}

Along with the changing culture of modern society that positions tourist visits as a necessity that must be considered at this time, Yogyakarta is one of the tourist destinations so that tourists visit the tourist attractions in Yogyakarta. However, if we pay more attention to the attractions offered, the development of tourism objects in Yogyakarta actually has not shown a significant development.

Community-based tourism development policies (CBT) need to be realized in real terms. CBT can motivate people to play an active role in tourism activities. Tourism village is one of the cultural tourist destinations managed by the village community in Yogyakarta. Therefore, it is appropriate that the community in the tourism village in Yogyakarta participate in managing their territory so that they are able to become a resource that can increase the tourism potential in their area, including the people of Dipowinatan Tourism Village.

Community participation in Dipowinatan Tourism Village has actually been implemented although not all residents participate in managing tourist destinations in the village. However, citizen participation should not only be realized in managing cultural attractions and other cultural tourism, but participation in disseminating information intensively to a wider community regarding the existence of Dipowinatan Tourism Village.

Hence, to realize sustainable tourism, there is a need for participation from the community in which the community is involved in the implementation of tourism 
policies through the management of tourism villages both through participation in cultural tourism and participation in providing information to a wider community.

\section{Acknowledgment}

We are very grateful to the parties who are willing to be interviewed for their time, willingness and friendliness, Mr. Sigit, the Head of Dipowinatan Tourism Village Manager, Mr. Triawan, Mr. Tony and the residents of Dipowinatan Tourism Village who have helped through interviews and discussions. Ms. Afra and Mrs. Demetria who have supported the preparation of this paper.

\section{References}

\section{Book}

Abidin, Said Zainal. (2016). Kebijakan Publik. Jakarta: Salemba Humanika.

Bevir, Mark. (2011). The Sage Handbook of Governance. London: SAGE Publication Ltd.

Brinkerhoff, Derick W., dan Benyamin L. Crosby. (2002). Managing Policy Reform, Concepts and Tools for Decision Makers in Developing and Transitioning Countries. USA: Kumarian Press, Inc.

Dinas Pariwisata Daerah Istimewa Yogyakarta. (2017). Buku Statistik Kepariwisataan Daerah Istimewa Yogyakarta Tahun 2017. Dinas Pariwisata Daerah Istimewa Yogyakarta

Damanik, Phil Janianton. (2013). Pariwisata Indonesia Antara Peluang dan Tantangan. Yogyakarta: Pustaka Pelajar.

Hakim, Luqman. (2013). Problem Demokratisasi dan Good Governance di Era Reformasi. Malang: UB Press.

Kartika, Citrawati Fitri, Imam, \& Hermawan (2012). Good Environmental Governance. Malang: UB Press.

Lele, Gabriel. (2016). Kebijakan Publik dan Pemerintahan Kolaboratif, Isu-isu Kontemporer. Editor Ag. Subarsono. Yogyakarta: Gava Media.

Patilima, Hamid. (2016). Metode Penelitian Kualitatif. Bandung: Alfabeta.

Pitana, I Gde dan I Ketut Surya Diarta. (2009). Pengantar Ilmu Pariwisata. Yogyakarta: Andi Offset

Santosa, Panji. (2008). Administrasi Publik, Teori dan Aplikasi Good Governance. Bandung: Refika Aditama. 
Sedarmayanti. (2009). Reformasi Administrasi Publik, Reformasi Birokrasi dan Kepemimpinan Masa Depan. Bandung: Refika Aditama.

. (2012). Good Governance, Kepemerintahan yang Baik, Dalam Rangka Otonomi Daerah Upaya Membangun Organisasi Efektif dan Efisiensi melalui Restrukturusasi dan Pemberdayaan. Bandung: Mandar Maju.

(2014). Membangun dan Mengembangkan Kebudayaan dan Industri Pariwisata (Bunga Rampai Tulisan Pariwisata). Bandung: Refika Aditama.

Sjamsuddin, Sjamsiar. (2005). Kepemerintahan dan Kemitraan. Malang: Yayasan Pembangunan Nasional.

Subarsono, Ag. (2009). Analisis Kebijakan Publik. Yogyakarta: Pustaka Pelajar.

Sugiyono. (2016). Memahami Penelitian Kualitatif. Bandung: Alfabeta.

Sumarto, Hetifah Sj. (2009). Inovasi, Partisipasi, dan Good Governance. Jakarta: Yayasan Obor Indonesia.

Sunaryo, Bambang (2013) Kebijakan Pembangunan Destinasi Pariwisata. Yogyakarta: Gava Media.

Tahir, Arifin. (2015). Kebijakan Publik dan Transparansi Penyelenggaraan Pemerintah Daerah. Bandung: Alfabeta.

Winarno, Budi. (2008). Kebijakan Publik, Teori dan Proses. Jakarta: Buku Kita.

\section{Journal Article}

Butler, Gareth. (2015). Fostering community empowerment and capacity building through tourism: perspectives from Dullstroom, South Africa. Journal of Tourism and Cultural Change. ISSN: 1476-6825 (Print) 1747-7654.

Krutwaysho, Oratai and Bill Bramwell Sheffield. (2010). Tourism Policy Implementation and Society. Annals of Tourism Research, Vol. 37, No. 3. pp. 670691.

Harto, Safri . (2017). Community Empowerment Through the Development of Tourism Village (A Case Study: Tourism Village of Penyengat Island, Tanjung Pinang, Riau Islands. International Journal of Economic Research. Volume 14, Issue 2, 2017. University of Riau, Pekanbaru, Indonesia, hal 227 - 240.

Pradono, Pradono, Budi Faisal, Yani Adriani, R. Rikeu, R. Fajriasanti. (2016). Towards Model of Community Economic Empowerment through Tourism Activities in Bogor Regency, West Java. Indonesia, International Journal of Economics and Financial Issues. 2016, 6(S6) 46-49. 
Suntikul, Wantanee, Stephen Pratt, Wallace I Kuan, Chao In Wong, Choi Cheng Chan, Wai Leng Choi \& Oi Fong Chong. (2016). Impacts of Tourism on the Quality of Life of Local Residents in Hue, Vietnam. An International Journal of Tourism and Hospitality Research. ISSN: 1303-2917 (Print) 2156-6909, Hal 1 - 16.

\section{Interview}

Sigit (2017, December 22). Personal interview.

Triawan (2017, December 7). Personal interview

Tony (2017, December 8). Personal interview

\section{Internet}

M Nur Huda. (2015, April 1). Sri Sultan Gerah Lihat Hotel di Yogya Menjamur. http://jogja.tribunnews.com/2015/04/01/sri-sultan-gerah-lihat-hotel-di-yogyamenjamur (diakses 2 September 2017)

Hamim Thohari. (2016, September 24). Berwisata dan Mengenal Tradisi Jawa di Kampung Dipowinatan Yogyakarta. http://jogja.tribunnews.com/2016/09/24/berwisata-dan-mengenal-tradisijawa-di-kampung-dipowinatan-yogyakarta?page=3 (diakses 2 September 2017)

\section{Regulation}

Perwali Yogyakarta Nomor 115 Tahun 2016 Tentang Penyelenggaraan Kampung Wisata

Peraturan Walikota Yogyakarta Nomor 55 Tahun 2016 Tentang Pengendalian Pembangunan Hotel 